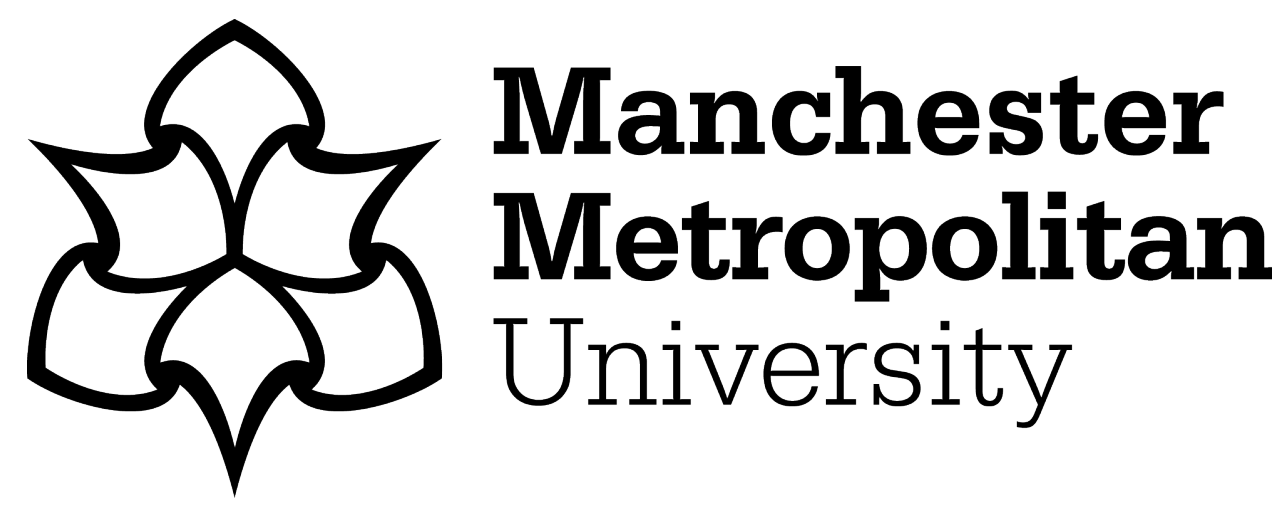

Rose-Redwood, R, Vuolteenaho, J, Young, C and Light, D (2019) Naming rights, place branding, and the tumultuous cultural landscapes of neoliberal urbanism. Urban Geography, 40 (6). pp. 747-761. ISSN 0272-3638

Downloaded from: https://e-space.mmu.ac.uk/626053/

Version: Accepted Version

Publisher: Taylor \& Francis

DOI: https://doi.org/10.1080/02723638.2019.1621125

Please cite the published version 


\title{
Naming rights, place branding, and the tumultuous cultural landscapes of neoliberal urbanism
}

\author{
Reuben Rose-Redwood, Jani Vuolteenaho, Craig Young \& Duncan Light
}

To cite this article: Reuben Rose-Redwood, Jani Vuolteenaho, Craig Young \& Duncan Light (2019) Naming rights, place branding, and the tumultuous cultural landscapes of neoliberal urbanism, Urban Geography, 40:6, 747-761, DOI: 10.1080/02723638.2019.1621125

To link to this article: https://doi.org/10.1080/02723638.2019.1621125

曲 Published online: 27 May 2019. 


\title{
Naming rights, place branding, and the tumultuous cultural landscapes of neoliberal urbanism
}

\author{
Reuben Rose-Redwood (iD ${ }^{a}$, Jani Vuolteenaho ${ }^{b}$, Craig Young $\mathbb{D D}^{c}$ and Duncan Light ${ }^{d}$ \\ aDepartment of Geography, University of Victoria, Victoria, Canada; ${ }^{b}$ Faculty of Social Sciences, University \\ of Helsinki, Helsinki, Finland; 'Division of Geography and Environmental Management, Manchester \\ Metropolitan University, Manchester, UK; 'Department of Tourism and Hospitality, Bournemouth \\ University, Bournemouth, UK
}

\begin{abstract}
In recent decades, urban policymakers have increasingly embraced the selling of naming rights as a means of generating revenue to construct and maintain urban infrastructure. This practice of "toponymic commodification" first emerged with the commercialization of professional sports during the second half of the 20th century and has become an integral part of the policy toolkit of neoliberal urbanism more generally. As a result, the naming of everything from sports arenas to public transit stations has come to be viewed as a sponsorship opportunity, yet such naming rights initiatives have not gone uncontested. This special issue examines the political economy of urban place naming through a series of case studies that consider how the commodification of naming rights is transforming the cultural landscapes of contemporary cities. In this introductory article, we provide an overview of the geographies of toponymic commodification as an emerging research focus within the field of critical urban toponymies and propose several theoretical approaches that can enhance our understanding of the commodification of naming rights as an urban spatial practice. We then discuss the main contributions in this special issue and conclude by exploring potential directions for future research on the geographies of urban toponymic commodification.
\end{abstract}

\section{ARTICLE HISTORY}

Received 6 May 2019

Accepted 14 May 2019

\section{KEYWORDS}

Critical toponymy; naming rights; toponymic commodification; place branding; cultural landscapes; neoliberal urbanism

\section{Introduction}

On 1 December 2016, the Los Angeles County Metropolitan Transportation Authority (MTA) approved a policy allowing corporate sponsors to purchase the right to rename "a rail line, bus line, station or building by stamping their name and logo all over the facility, across station signs and locator graphics as well as digital incarnations such as Google maps or other online directional services" (Scauzillo, 2016). Within less than three months, the very same governing body repealed its new naming rights policy due to concerns that it would result in the over-commercialization of public space and potentially lead to lawsuits if the MTA denied a corporation's naming rights proposal (Nelson, 2017; Scauzillo, 2017). Meanwhile, in Saudi Arabia's capital city, Riyadh, 
governmental authorities announced in 2018 that they had acquired over $\$ 200$ million (USD) in naming rights contracts for eight metro stations (Bridge, 2018), thereby joining a growing number of cities worldwide - from New York to Dubai - that have embraced naming rights sponsorships as a means of generating revenue for the development and maintenance of public infrastructure.

Historically, the selling of naming rights for urban landmarks traces back to two primary sources: philanthropic gifting and the commercialization of professional sports. Over the past two decades, however, the commodification of naming rights has become a seemingly ubiquitous practice with city governments, transportation authorities, hospitals, universities, environmental conservation groups, and other non-governmental organizations selling the naming rights for everything from convention centers and sports arenas to public parks and even newly discovered species (Burton, 2008). As a form of public-private partnership, naming rights sponsorships are a political technology of neoliberal governance that have played a significant role in the commodification of urban place-identities. The process of toponymic commodification - that is, the use of place names, or toponyms, as commodities - is radically transforming the identities of public places into marketized assets, the value of which is increasingly being framed solely in terms of a name's rentgenerating capacity.

Proponents argue that the sale of naming rights offers an innovative strategy to generate municipal revenue without raising taxes, whereas scholars and grassroots activists in different urban and national contexts have maintained that naming rights sponsorships commercialize, and thus erode the democratic value of, urban public spaces. Although there is a long history of places being named after wealthy elites, property owners, and corporations, the contributions to this special issue illustrate that the proliferation of naming rights agreements in recent decades is historically unprecedented in terms of its scope and the interest in toponymic commodification within urban policymaking circles. Naming rights contracts have also changed as "time-limited" naming rights agreements have become the norm in comparison with more traditional forms of philanthropic naming in which an honorific name is bestowed in perpetuity. The time-limited nature of most contemporary naming rights agreements has resulted in urban namescapes that remain in a constant state of flux as one corporate sponsor's name replaces another when naming rights contracts expire. These tumultuous changes in the place-identities of major urban landmarks have significant implications for urban wayfinding and the creation of a "sense of place" in contemporary cities.

Despite its growing importance as an urban policy practice, few urban scholars have critically examined the geographies of urban naming rights and toponymic commodification (yet, see Light \& Young, 2015; Medway \& Warnaby, 2014; Rose-Redwood, 2011; RoseRedwood, Alderman, \& Azaryahu, 2010). The primary goal of this special issue is to showcase empirically-grounded and theoretically-informed case studies of how the commodification of naming rights and the use of place naming as a city branding strategy have become integral to the workings of neoliberal urbanism. Our overarching aim is therefore to contribute to geographical scholarship on urban neoliberalization by examining how the processes of commodification have extended into controversial new arenas of urban place-making that are reshaping the cultural landscapes of cities around the world.

In the remainder of this introductory article, we situate recent scholarship on toponymic commodification within the broader literature on critical toponymies. 
Next, we consider various theoretical approaches that have been, or might productively be, employed to study the geographies of toponymic commodification. We then discuss the main contributions that this special issue makes toward developing a body of urban geographical scholarship on the commodification of naming rights and its role in the neoliberalization of urban space. Lastly, the article concludes by suggesting potential directions for future research on urban toponymic commodification as a spatial strategy of neoliberal urbanism.

\section{Toponymic commodification and the geographies of urban naming rights: an emerging field of study}

The study of toponymic commodification is an emerging area of scholarship within the field of critical urban toponymy. The geography of place naming has long been of interest to geographers and other scholars, and there is a well-established body of literature which has explored the important role that naming plays in the production of space and place. Early toponymic scholarship primarily adopted encyclopedic, etymological, and archaeological approaches, resulting in gazetteers and dictionaries of place names as well as using toponymy to reconstruct the history of settlement within a region and the influence of past cultures on the landscape (for a review of early place name studies, see Wright, 1929). In recent years, however, the study of place naming has been reanimated through the emergence of critical toponymies, which refers to a growing body of research that critically examines the politics of place naming practices (Berg \& Vuolteenaho, 2009; Giraut \& Houssay-Holzschuch, 2016; Rose-Redwood et al., 2010).

During the 1990s, a number of seminal works highlighted how the naming of places, streets, and urban landmarks was implicated in political projects such as nationbuilding, state formation, and the spatialization of collective memory (Azaryahu, 1996; Berg \& Kearns, 1996; Cohen \& Kliot, 1992; Myers, 1996; Yeoh, 1996). Building on these classic studies, a new wave of critical toponymic scholarship extended this work by analyzing a range of case studies related to the politics of (re)naming places in a variety of geographical contexts, with a particular focus on colonial/postcolonial, postApartheid, and socialist/postsocialist settings (Bigon, 2009; Duminy, 2014; Light, 2004; Light \& Young, 2014; Wanjiru \& Matsubara, 2017). A parallel body of research has also linked naming and renaming to the politics of race, gender, class, and the geographies of social justice (Alderman, 2002; Alderman \& Inwood, 2013; Rose-Redwood, 2008; Rose-Redwood et al., 2010; Rose-Redwood, Alderman, \& Azaryahu, 2018).

Over the past decade, there has been increasing attention not only to the politics of place naming but, more specifically, to the political economy of toponymic commodification (Light \& Young, 2015; Medway \& Warnaby, 2014; Rose-Redwood \& Alderman, 2011; Rose-Redwood et al., 2010; Sotoudehnia \& Rose-Redwood, 2019). This focus on the "toponym-as-commodity" (Rose-Redwood \& Alderman, 2011, p. 3) conceptualizes place naming as a form of symbolic capital, which can be converted into economic capital and exploited for its exchange value (Alderman, 2008; Light \& Young, 2015; Rose-Redwood et al., 2010). In particular, Rose-Redwood (2011) argues that the commercialization of urban place naming within contemporary neoliberal contexts is one of the most significant transformations that will affect the toponymic landscape during the 21st century (also, see Light \& Young, 2015). 
This focus on the commodification of urban toponymy thus constitutes an embryonic "second wave" of critical place name scholarship to which the current special issue contributes. The selling of naming rights for sports stadia to corporate sponsors - itself one of the longest-established ways in which place names have been turned into commodities - has been examined from a range of disciplinary perspectives including sports management (e.g. Eddy, 2014) and marketing (e.g. Woisetschläger, Haselhoff, \& Backhaus, 2014). Yet only recently have critical place name scholars begun to consider the commodification of sports stadia naming, the motives of the clubs themselves, and the reactions of ordinary fans (Gillooly \& Medway, 2019; Light \& Young, 2015; Medway \& Warnaby, 2014; Vuolteenaho \& Kolamo, 2012). Several of the articles in the current special issue further advance this line of scholarly inquiry.

Increasingly, geographers have begun to consider how toponymic commodification has extended beyond the realm of professional sports to become a political technology of neoliberal urbanism more generally (Light \& Young, 2015; Medway \& Warnaby, 2014; Sotoudehnia \& Rose-Redwood, 2019). Such studies examine how municipal authorities have embraced the selling of naming rights to public places - such as the naming of metro stations, public buildings, and other elements of a city's public infrastructure - as a means of coping with declining revenue transfers from central governments, austerity politics, global financial crises, and a prevailing neoliberal orthodoxy emphasizing the need for cities to be entrepreneurial and competitive (Light \& Young, 2015; Rose-Redwood, 2011). A related strand of research considers the influence of neoliberal urbanism on the (re) naming of urban neighborhoods, particularly in the context of private sector-led urban development projects (Berg, 2011; Madden, 2018; Masuda \& Bookman, 2018; Vuolteenaho \& Ainiala, 2009), thereby emphasizing struggles over access to, and belonging in, urban space in the neoliberal city.

Some studies have also focused on toponymic commodification as a form of city branding (Medway \& Warnaby, 2014; Sotoudehnia, 2013; Sotoudehnia \& RoseRedwood, 2019). Medway and Warnaby (2014), for example, argue that toponyms can serve as the basis for place brands but cannot be treated in the same way as conventional brand names. Moreover, place brands can be dissonant with both internal and external perceptions of a place (Medway, Swanson, Neirotti, Pasquinelli, \& Zenker, 2015). This points to the need for a deeper understanding of how place brands - and names - resonate with the stakeholders involved in both their creation and consumption. Addressing this latter issue, Hakala, Sjöblom, and Kantola (2015) explore the perceptions of local urban residents towards the renaming of municipalities in Finland. Their research suggests that local residents often show a strong attachment to existing place names and that stable names are essential in the construction of place brands.

The commodification of place naming also occurs in more idiosyncratic ways. For instance, Light (2014) examines the commodification of place naming in the context of tourism geographies and argues that unusual toponyms can themselves be attractions for tourists. Furthermore, place names are commodified in a diverse range of souvenirs (such as fridge magnets), which enable tourists to make connections with the places they visit. In a different context, Karimi (2016) considers place names as commodities in post-conflict Kabul but argues that such names were valued more as symbolic rather than economic capital. Finally, Sotoudehnia (2018) explores the adoption of "Makani" (a wayfinding tool based on geo-addressing software) in Dubai. She argues that this app 
represents a unique example of the "toponym-as-commodity" (Rose-Redwood \& Alderman, 2011) in that the data collected by the app could become commodities for sale to third parties, thereby contributing to the monetization of urban space. Similarly, Light and Young (2015) make related arguments about the privatization and commercialization of spatial data that were originally produced by public sector organizations.

As this review of the literature on the political economy of urban place naming illustrates, the commodification of urban toponymy is a key emerging research area. To date, the focus of this second wave of critical toponymic research is eclectic and fragmented, and this special issue aims to bring together a series of theoreticallyinformed case studies within a single volume to further enrich our understanding of the geographies of toponymic commodification in neoliberalizing cities.

\section{Theoretical perspectives on the political economies of urban place naming}

In response to the global upsurge in the commodification of naming rights as part of the neoliberalization of urban space, it is crucial for urban scholars to consider what different theoretical frameworks can offer for describing, interpreting, and critiquing the political economies of urban place naming. In this section, we briefly consider how theories of capitalist urbanization, symbolic capital, hegemony, and rhythmanalysis can provide insights into the production of commodified toponymic landscapes. These approaches are by no means the only theoretical frameworks available to examine the political economies of urban place naming. This theoretical discussion is therefore meant to be suggestive rather than comprehensive, and we hope that it will inspire greater theoretical reflection in subsequent geographical studies of toponymic commodification.

One of the most relevant sources of theoretical inspiration to critically examine the geographies of commodified urban toponymies are historical-geographical materialist accounts of capitalist urbanization. As Harvey (1985) argues, urbanization under capitalism is based upon the imperative to "create a social and physical landscape in its own image ... only just as certainly to undermine, disrupt and even destroy that landscape at a later point in time" (p. 150). From this perspective, the selling of naming rights to urban infrastructure can be understood as an extension of commodity relations to the realm of urban placeidentities. In particular, toponymic commodification is a rent-seeking practice that depends upon the exercise of a monopoly power over the naming of places (for a discussion of the concept of monopoly rent, see Harvey, 2012, pp. 89-112).

Both philanthropic and corporate-sponsored naming rights involve the exercise of a monopoly power over property (whether public or private), but not all forms of property function as marketized commodities. Philanthropic naming has historically involved a process whereby a donor provides a gift to an organization in return for naming rights in perpetuity. While the initial competition for securing a philanthropic naming right can be seen as a form of toponymic commodification, once a philanthropic naming right is bestowed, this generally has the effect of removing it from the potential market of commodified naming rights indefinitely. By contrast, time-limited naming rights sponsorships ensure that when naming rights are leased to sponsors for a given period of time, they will eventually be released back onto the naming rights market when the lease expires. The timelimited quality of naming rights sponsorships transforms a naming right into a rentgenerating, marketable commodity. 
A significant geographical consequence of the shift to time-limited naming rights is the destabilization of urban namescapes, since corporate-sponsored place names often change when naming rights contracts are renegotiated, thereby contributing to what urban geographers have called the "restless" urban landscape (Knox, 1991). Toponymic commodification is thus part of the broader process of creative destruction that characterizes capitalist urbanization, which, as Harvey contends, "must negotiate a knife-edge between preserving the values of past commitments ... or devaluing them to open up fresh room for accumulation" (1985, p. 150). The selling of timelimited naming rights devalues "past commitments" of place naming in order to "open up fresh room for accumulation" for both public and private property owners while also generating public visibility in the city for corporate brands as part of a sponsor's marketing strategy. It is hardly surprising, then, that the proliferation of commodified naming rights has gone hand-in-hand with the rise of "entrepreneurial municipalities" that have internalized neoliberal imperatives (Lauermann, 2016). Historicalgeographical materialist approaches to capitalist urbanization therefore provide important conceptual tools to explain how the commodification of naming rights contributes to the tumultuousness of urban landscapes within the context of neoliberal urban governance. Yet acknowledging the role of toponymic commodification as a strategy of neoliberal urbanism is only a starting point, rather than a closing argument, for theorizing the political economy of urban place naming.

Another theoretical framework that has considerable potential to critically analyze the geographies of naming rights is Bourdieu's (1990) theory of symbolic capital. The public recognition and visibility associated with the naming of places bestows a sense of prestige, or symbolic capital, upon the individuals or corporate entities recognized through place naming. According to symbolic capital theory, one form of capital can potentially be converted into other forms of capital (Bourdieu, 1986). The commodification of naming rights is a classic example of how the symbolic capital of a place name can be converted directly into economic capital, and, conversely, how economic capital can literally be used to purchase symbolic capital in the form of toponymic recognition.

Yet while naming rights may acquire economic value through the formal act of exchange, commodified toponymies only acquire symbolic value to the extent that officially-sponsored place names are perceived to have value among various "publics" and are thus incorporated into the spatial practices of everyday life. If a naming right is ignored or outright resisted, its symbolic value may be diminished irrespective of its officially-recognized legal status. The owners of naming rights - as well as the accompanying industry of naming rights specialists, consultants, etc. - therefore have a vested interest in promoting the legitimacy of toponymic commodification and the popular use of commodified toponyms on official signage and maps as well as in the media and among ordinary urban residents.

One approach that can be drawn upon to critically examine these processes of toponymic legitimation is hegemony theory. Vuolteenaho and Puzey (2018) use Gramscian hegemony theory to consider the reciprocity of power relations within the context of street naming and offer a model to develop an understanding of the circumstances under which people tend to accept commodified naming rights as an urban namescape's "new normal" (cf. Harvey, 2012, pp. 156-157). Hegemonic power operates through the production of particular socio-spatial 
relations as the taken-for-granted order of everyday life in order to govern through consent rather than force alone. The selling of naming rights is often framed by its promoters as a commonsensical practice that aligns with the prevailing wisdom of entrepreneurial governance in the neoliberal city, and it can therefore be viewed as an attempt to assert hegemonic power over urban place naming.

However, resistance to toponymic commodification does occur, and if we follow Laclau (2018 [2005]) in defining the act of naming as constituting "a highly cathected rallying point" (p. 231), this can help us make sense of what mobilizes people to individually or collectively resist the commodification of naming rights and the corporatized urban spaces which it produces. For those who inhabit cities, the "in-built" or "scripted" effects of naming rights may not only result in perpetually eroding the honorific significance of urban place naming as well as the place-anchored use values of toponymy; such practices also result in technical-cartographic instability and spatiocognitive evanescence (Boyd, 2000). One potential direction to come to terms with these effects could be to take a cue from Lefebvrian rhythmanalysis (Lefebvre, 2004). This approach could trace the trajectories, time-frames, and everyday repercussions of toponymic commodification by focusing on the temporal pulses of place (re)naming events (i.e. the initiation or expiration of naming rights agreements) across different time periods or urban jurisdictions, and how distinct toponymic rhythms enter the lived worlds - i.e. biographical life-cycles, spatio-temporal practices, and forms of toponymic attachment - of different urban populations.

The theoretical perspectives outlined above provide several useful entry points to developing critical theorizations of toponymic commodification, yet urban scholars have only begun to theorize the spatio-temporalities of urban naming rights. The articles in this special issue are an important step forward in extending our empirical knowledge and theoretical understanding of the political economy of toponymic commodification, and it is to these contributions that we now turn.

\section{Contributions toward a critical geography of urban toponymic commodification}

Given the lack of geographical scholarship on the political economy of urban naming rights, the studies in this special issue break new ground in contributing to the development of a critical geography of toponymic commodification. They do so using a variety of research methodologies - including quantitative comparative analysis, qualitative case studies, fieldwork, and digital media analysis - as well as different theoretical frameworks such as theories of cultural hegemony, symbolic capital, monopoly power, rent, scalar politics, urban policy mobilities, and techno-imperialism. The contributors examine the geographies of urban toponymic commodification in a diverse array of geographical locales. In particular, they consider case studies ranging from the selling of naming rights for sports arenas in European cities and metro stations in Dubai to the failed attempt at renaming a New Zealand/Aotearoa town as part of a neoliberal place branding strategy and the role of philanthropic naming in the "Facebookification" of San Francisco's gentrifying neighborhoods. The articles in this collection not only document the growing prevalence of urban naming rights globally 
but also demonstrate how different public and private actors have perceived the phenomenon of toponymic commodification in divergent ways.

The first three studies focus on the commodification of naming rights in the realm of professional sports within the European urban context. Sports arenas are major landmarks in many contemporary cities, and their public visibility in the urban landscape as well as through media coverage of sporting events has made them primary sites for naming rights sponsorships. Vuolteenaho, Wolny, and Puzey (2019) provide a systematic, comparative analysis of the spread of naming rights sponsorships for sports and entertainment venues in England and Wales, Finland, Germany, Italy, Norway, and Scotland. Using both quantitative and qualitative data on over 300 football (soccer) grounds and indoor arenas, they analyze the geographies of naming rights and tensions around them as "a particular 'cultural' aspect in the world-wide mobilization of entrepreneurial discourses" associated with neoliberal urbanism. More specifically, they document how an increasing number of sporting and entertainment facilities in European cities have become stages for naming rights sponsorship contracts over the last three decades. Overall, the authors estimate that a combined total of $38 \%$ of all football grounds and indoor arenas in their study sites have been named after sponsors (33.2\% of football grounds and $46.1 \%$ of indoor arenas, respectively), with many older football grounds representing iconic landmarks and community symbols whose sponsorship-based renaming has often met local opposition. Additionally, the adoption of naming rights sponsorships has been anything but uniform across Europe due to locally and nationally differing economic and regulatory circumstances as well as variably intensive civic and fan contestations. For instance, the highest proportion of football grounds have been named after sponsors in Germany (74.3\%) compared to a low of $8 \%$ in Italy. Another intriguing difference is that naming rights agreements tend to be tailored for considerably shorter periods in smaller, more impecunious, European urban settings than in bigger cities with premium infrastructures and stronger economic clout.

Medway, Warnaby, Gillooly, and Millington (2019) explore the "scalar tensions" that have arisen among football club owners and fan communities in relation to three corporate naming rights sponsorships for football stadia in the Greater Manchester Region of the UK. Drawing upon a series of interviews and on-site fieldwork, their study highlights the place branding strategies of club owners; how corporate names have been embedded into the urban landscape; and the contrasting responses that commodified naming has received among different fan bases. The findings suggest that fan resistance to toponymic commodification is strongest in cases where a sports stadium has "occupied the same location with the same name" for an extensive period of time, leading fans to develop an emotional attachment to its traditional, noncommodified place-identity. By contrast, when a football team relocates to a new stadium in a different location, fans will likely be "far less resistant to the imposition of a corporate toponym." This underscores the importance of understanding the relationality of place naming as well as the emotional geographies of place attachment as a scalar phenomenon. Following Hagen's (2011) call for more research on the intersections between the geographies of place naming and the politics of scale, Medway et al. convincingly argue that the corporate naming of sports arenas is a key process through which tensions over the scalar politics of place are currently unfolding as part of "the corporate creep of neoliberal intervention in the toponymic landscape of towns and cities." 
Crețan (2019) likewise explores the conflicting responses of sports fans to the selling of naming rights, in this case for a football team named "Poli" in Timişoara, Romania, following the fall of communism. Although much of the literature on naming rights has focused on fixed capital in the form of urban infrastructure - sports arenas, convention centers, etc. - Crețan's study considers how the commodification of naming rights for a sports team's identity resulted in the fragmentation of urban fan communities and competing claims over the legitimate use of a name. To generate revenue, the local authorities in Timişoara sold the naming rights of a football team that had been known since it was established in 1921 by the name of Poli Timişoara (or Poli) to a wealthy investor, who renamed the team Fotbal Club Universitatea Timişoara (FCU Timişoara). A decade later, the naming rights were resold to another investor, who was subsequently convicted of using the team's financial accounts in a money laundering scheme. Due to the investor's financial mismanagement, the team acquired significant debt and was disbanded. Local authorities and corporate sponsors responded by creating a new team largely composed of players from a neighboring town, which they named Asociația Club Sportiv Politehnica Timişoara (ACS Poli). However, the majority of local fans supported another team, Asociația Sportivă Universitară Politehnica Timişoara (ASU Poli), since most of the original Poli players were on the latter team. Based on 120 interviews with fans from both Poli teams, Crețan examines how inequalities in political, economic, and social capital shape struggles over cultural hegemony, place identity, and community, and how the right to name provides a focal point around which such conflicts may coalesce. This study therefore serves as a useful reminder that the commodification of naming rights can have unintended consequences that may increase social divisiveness within local communities.

Despite encountering resistance in some cases, the selling of naming rights has become a key aspect of the commercialization of sports over the past three decades, and many urban policymakers have also embraced toponymic commodification as an entrepreneurial strategy of neoliberal urban governance. Rose-Redwood, Sotoudehnia, and Tretter (2019) draw upon 37 interviews, on-site fieldwork, and archival materials to provide a comparative analysis of urban naming rights programs in Dubai (United Arab Emirates) and Winnipeg (Canada). Extending Bourdieu's (1990) work on symbolic capital, they argue that urban toponymic commodification is a prime example of symbolic/economic capital transformations in which the symbolic distinction bestowed through the naming of public places is converted directly into economic capital in the form of what they call "naming rent." The authors observe that viewing the spatial identities of urban public places as rent-generating assets has the "effect of privileging the potential economic exchange value of urban toponyms over other potential non-market values associated with urban place naming." By comparing Dubai's Metro Naming Rights Initiative with the Sponsor Winnipeg Program, their study also highlights the variegated outcomes of urban naming rights programs - with Dubai's initiative far surpassing Winnipeg's program in terms of the sponsorship revenue generated. They maintain that scope and visibility are crucial to understanding these divergent outcomes, and they conclude that "the revenue generated from urban naming rights programs does not always meet the optimistic expectations of policymakers." While some urban residents in both Dubai and Winnipeg raised concerns about the crass commercialism of toponymic commodification, others were generally 
indifferent to the issue, leading Rose-Redwood et al. to suggest that commodified toponymies are increasingly becoming normalized as part of everyday urban landscapes.

Yet the normalization of toponymic branding is not always a seamless process, as Kearns and Lewis (2019) demonstrate by considering a failed attempt among business elites in New Zealand/Aotearoa to rename an entire town in order to enhance its international reputation through brand promotion. In 2016, local business leaders led a campaign to rename the town of Blenheim (Waiharakeke in Māori) as "Marlborough City" since the Marlborough region in which the town is located is internationally renowned for its wine industry. Kearns and Lewis critically examine media coverage of the renaming proposal and the contentious debate that ensued. They contend that the campaign to rename Blenheim was a neoliberal project of place-making that was based upon a "pervasive yet nebulous economic nationalism that seeks to yoke all local and national identity to enhancing export growth." The authors see the failure of this place branding scheme as indicative of the limits to neoliberal urbanism when it is strongly opposed by those seeking to defend the "heritage" of place or reclaim indigenous toponymies. The issues at stake, of course, depend upon the context in which place naming occurs, and Kearns and Lewis's study exemplifies how the politics of profit-driven place naming and branding practices are always placespecific and intertwined with existing power relations in a given society.

Toponymic inscription has long been employed as a political technology of dispossession, erasure, and the imperialist appropriation of territory, and McElroy (2019) illustrates how the selling of philanthropic naming rights to wealthy elites is currently implicated in the material and discursive dispossession of socially marginalized groups as "techno-imperialism" transforms the fabric of urban spaces and communities. As a case in point, McElroy focuses on the renaming of a public hospital in San Francisco as the "Zuckerberg San Francisco General Hospital and Trauma Center" in 2015 after Facebook's CEO Mark Zuckerberg donated \$75 million toward renovating the hospital (while a significant sum of money, it was less than $10 \%$ of the total public funds provided for hospital renovations). McElroy argues that, when tied to the acquisition of naming rights for urban public places, philanthropic donations should be understood not as a "gift" but rather as "a self-interested promotional strategy." Based on extensive participatory action research with anti-eviction activists in San Francisco, McElroy links the renaming of "The General" as "The Zuckerberg" with the broader politics of techdriven gentrification in the city. This latter process of urban redevelopment has resulted in the eviction of long-time local residents and contributed to negative health outcomes for those who have been displaced (in some cases likely contributing to premature death due to the stress of relocation, particularly for low-income, elderly residents of color). McElroy highlights the irony of Zuckerberg's name being symbolically associated with promoting "health" in the city while Facebook and other tech companies are placing the health and wellbeing of vulnerable populations at further risk through displacement and dispossession.

\section{Future research directions}

From sports arenas to metro stations, hospitals, and other public places, the commodification of naming rights continues to remake urban cultural landscapes in the 21st century. The contributions to this special issue draw attention to the diverse ways in 
which toponymic commodification is transforming the identities of public places into time-limited, rent-generating commodities. By delving into the intricacies of particular case studies of urban naming rights and toponymic branding, these articles make a significant contribution toward developing a more in-depth understanding of naming rights as an arena of political, economic, and cultural contestation over the production of urban space. Yet there is much work that remains to be done, and we conclude by proposing a number of potential avenues for future research on the geographies of urban toponymic commodification. Among other topics of scholarly concern, future research might address the following thematic areas:

(1) Institutional ethnographies of the naming rights sponsorship industry. The selling of naming rights is a multi-million dollar industry, and there are numerous consultancy firms that promote and facilitate the sale of naming rights globally. The naming rights industry also conducts its own marketing research and holds conferences and workshops where "best practices" are circulated among those in the industry as well as potential clients in government, the corporate world, and the non-profit sector. Conducting institutional ethnographies of particular naming rights firms or the industry as a whole - through participant observation at conferences, workshops, and other industry-related events; interviews with key actors; and critically examining industry magazines, newsletters, and other publications - could offer new insights into the processes driving the naming rights agenda.

(2) Urban policy mobilities and the uptake of naming rights among urban policymakers. As naming rights policies become more widespread, future research should examine how knowledges of naming rights policies and practices circulate among urban policymakers. Such studies could also consider what leads some governmental entities to embrace naming rights policies while others reject such policies.

(3) Reception and resistance to toponymic commodification. Few studies have considered how urban residents, sports fans, etc., perceive naming rights sponsorships in different geographical locales and contexts. A number of the studies in this special issue address this matter, but further research is needed to better understand the reception of commodified toponymies in everyday speech and the extent to which there have been movements to resist the commodification of public place-identities through forms of toponymic activism. This can build upon the extensive body of research undertaken within the first wave of critical place name studies, which has focused on resistance to, and contestation of, practices of (re)naming urban places.

(4) Critical quantitative analyses of naming rights policy outcomes. How successful have urban naming rights policies been on their own terms with respect to net revenue generation in different urban contexts from small towns to large cities? This pragmatic question could serve as the basis of an applied research agenda that uses the techniques of economic calculation to potentially challenge the selfpromotional claims of the naming rights industry and over-confident urban politicians who are convinced that naming rights sponsorships will generate vast sums of revenue for urban infrastructure. 
(5) Addressing power disparities in the uneven development of urban naming rights. There is a need to develop new ways to theorize the power relations associated with the accumulation of economic and symbolic capital through the commodification of naming rights as well as the uneven development of naming rights geographies across different spatial and temporal scales. Although it is challenging to map the uneven geographies of naming rights markets globally, it is clear that the sums involved in naming rights transactions in the peripheries and semi-peripheries of the world economy pale in comparison to their counterparts nearer its hubs. Only fleeting mention of these power disparities has been made in the scholarly literature on toponymic commodification, and this issue thus deserves further consideration. The same notion applies to the elevated status of English as the lingua franca of latemodern, advanced capitalism (Heller, 2010). In many contexts with a subaltern position on the global map of linguistic power relations, commercial toponymies adopted or transmogrified from the Anglophone world are a key instrument to mobilize symbolic capital (Yurchak, 2000). Meanwhile, these re-inscriptions of a global hegemony are seductive for some locals but irksome for others, all of which contributes to urban naming rights serving as a contested emblem of our neoliberal times.

The themes outlined here are by no means exhaustive of the potential directions of future research on the geographies of urban naming rights. Yet regardless of what issues are considered, it is high time for geographers and other scholars to critically engage with the spatial politics of urban toponymic commodification, and we hope that the current special issue will encourage other urban researchers to join us in critically analyzing toponymic commodification as one among many political technologies of neoliberal urbanism.

\section{Disclosure statement}

No potential conflict of interest was reported by the authors.

\section{ORCID}

Reuben Rose-Redwood (iD http://orcid.org/0000-0001-6384-5877

Craig Young (D) http://orcid.org/0000-0002-4324-1483

\section{References}

Alderman, Derek. (2002). Street names as memorial arenas: The reputational politics of commemorating Martin Luther King in a Georgia county. Historical Geography, 30, 99-120.

Alderman, Derek. (2008). Place, naming, and the interpretation of cultural landscapes. In Brian Graham \& Peter Howard (Eds.), The Ashgate research companion to heritage and identity (pp. 195-213). Aldershot: Ashgate.

Alderman, Derek, \& Inwood, Joshua. (2013). Street naming and the politics of belonging: Spatial injustices in the toponymic commemoration of Martin Luther King Jr. Social \& Cultural Geography, 14(2), 211-233.

Azaryahu, Maoz. (1996). The power of commemorative street names. Environment and Planning D: Society and Space, 14(3), 311-330. 
Berg, Lawrence. (2011). Banal naming, neoliberalism, and landscapes of dispossession. ACME: an International Journal for Critical Geographies, 10(1), 13-22.

Berg, Lawrence, \& Kearns, Robin. (1996). Naming as norming: 'Race', gender, and the identity politics of naming places in Aotearoa/New Zealand. Environment and Planning D: Society and Space, 14(1), 99-122.

Berg, Lawrence, \& Vuolteenaho, Jani (Eds.). (2009). Critical toponymies: The contested politics of place naming. Burlington, VT: Ashgate.

Bigon, Liora. (2009). Urban planning, colonial doctrines and street naming in French Dakar and British Lagos, c. 1850-1930. Urban History, 36(3), 426-448.

Bourdieu, Pierre. (1986). The forms of capital. In John Richardson (Ed.), Handbook of theory and research for the sociology of education (pp. 241-258). New York, NY: Greenwood Press.

Bourdieu, Pierre. (1990). In other words: Essays towards a reflexive sociology. Stanford: Stanford University Press.

Boyd, Josh. (2000). Selling home: Corporate stadium names and the destruction of commemoration. Journal of Applied Communication Research, 28(4), 330-346.

Bridge, Sam. (2018, November 16). Riyadh metro naming rights auction raises $\$ 278 \mathrm{~m}$. Arabian Business. Retrieved from https://www.arabianbusiness.com/transport/408244-riyadh-metronaming-rights-auction-raises-278m

Burton, Terry. (2008). Naming rights: Legacy gifts and corporate money. Hoboken, NJ: Wiley.

Cohen, Saul, \& Kliot, Nurit. (1992). Place names in Israel's ideological struggle over the administered territories. Annals of the Association of American Geographers, 82(4), 653-680.

Crețan, Remus. (2019). Who owns the name? Fandom, social inequalities and the contested renaming of a football club in Timişoara, Romania. Urban Geography. doi: 10.1080/ 02723638.2018 .1472444

Duminy, James. (2014). Street renaming, symbolic capital, and resistance in Durban, South Africa. Environment and Planning D: Society and Space, 32(2), 310-328.

Eddy, Terry. (2014). Measuring effects of naming-rights sponsorships on college football fans' purchasing intentions. Sport Management Review, 17(3), 362-375.

Gillooly, Leah, \& Medway, Dominic. (2019). Sponsorships, stadia and naming rights. In Simon Chadwick, Daniel Parnell, Paul Widdop, \& Christos Anagnostopoulos (Eds.), Routledge handbook of football business and management (pp. 199-208). London: Routledge.

Giraut, Frédéric, \& Houssay-Holzschuch, Myriam. (2016). Place naming as dispositif: Toward a theoretical framework. Geopolitics, 21(1), 1-21.

Hagen, Joshua. (2011). Theorizing scale in critical place-name studies. ACME: an International Journal for Critical Geographies, 10(1), 23-27.

Hakala, Ulla, Sjöblom, Paula, \& Kantola, Satu-Paivi. (2015). Toponyms as carriers of heritage: Implications for place branding. Journal of Product and Brand Management, 24(3), 263-275.

Harvey, David. (1985). The geopolitics of capitalism. In Derek Gregory \& John Urry (Eds.), Social relations and spatial structures (pp. 128-163). London: Macmillan.

Harvey, David. (2012). Rebel cities. London: Verso.

Heller, Monica. (2010). The commodification of language. Annual Review of Anthropology, 39, 101-114.

Karimi, Ali. (2016). Street fights: The commodification of place names in post-Taliban Kabul City. Annals of the Association of American Geographers, 106(3), 738-753.

Kearns, Robin, \& Lewis, Nicolas. (2019). City renaming as brand promotion: Exploring neoliberal projects and community resistance in New Zealand. Urban Geography. doi: 10.1080/ 02723638.2018.1472445

Knox, Paul. (1991). The restless urban landscape: Economic and sociocultural change and the transformation of metropolitan Washington, DC. Annals of the Association of American Geographers, 81(2), 181-209.

Laclau, Ernesto. (2018 [2005]). On populist reason. London: Verso.

Lauermann, John. (2016). Municipal statecraft: Revisiting the geographies of the entrepreneurial city. Progress in Human Geography, 42(2), 205-224. 
Lefebvre, Henri. (2004). Rhythmanalysis: Space, time and everyday life. London: Continuum.

Light, Duncan. (2004). Street names in Bucharest, 1990-1997: Exploring the modern historical geographies of post-socialist change. Journal of Historical Geography, 30(1), 154-172.

Light, Duncan. (2014). Tourism and toponymy: Commodifying and consuming place names. Tourism Geographies, 16(1), 141-156.

Light, Duncan, \& Young, Craig. (2014). Habit, memory and the persistence of socialist-era street names in post-socialist Bucharest, Romania. Annals of the Association of American Geographers, 104(3), 668-685.

Light, Duncan, \& Young, Craig. (2015). Toponymy as commodity: Exploring the economic dimensions of urban place names. International Journal of Urban and Regional Research, 39 (3), 435-450.

Madden, David. (2018). Pushed off the map: Toponymy and the politics of place in New York city. Urban Studies, 55(8), 1599-1614.

Masuda, Jeffrey, \& Bookman, Sonia. (2018). Neighbourhood branding and the right to the city. Progress in Human Geography, 42(2), 165-182.

McElroy, Erin. (2019). Data, dispossession, and Facebook: Techno-imperialism and toponymy in gentrifying San Francisco. Urban Geography, 1-20. doi: 10.1080/02723638.2019.1591143

Medway, Dominic, Swanson, Kathryn, Neirotti, Lisa Delpy, Pasquinelli, Cecelia, \& Zenker, Sebastian. (2015). Place branding: Are we wasting our time? Report of an AMA special session. Journal of Place Management and Development, 8(1), 63-68.

Medway, Dominic, \& Warnaby, Gary. (2014). What in a name? Place branding and toponymic commodification. Environment and Planning A, 46(1), 153-167.

Medway, Dominic, Warnaby, Gary, Gillooly, Leah, \& Millington, Steve. (2019). Scalar tensions in urban toponymic inscription: The corporate (re)naming of football stadia. Urban Geography. doi: 10.1080/02723638.2018.1446585

Myers, Garth. (1996). Naming and placing the other: Power and the urban landscape in Zanzibar. Tidjschrift Voor Economische En Sociale Geografie, 87(3), 237-246.

Nelson, Laura. (2017, February 27). Transit officials backtrack on controversial policy to sell naming rights for metro stations. Los Angeles Times. Retrieved from https://www.latimes.com/ local/lanow/la-me-ln-metro-naming-rights-20170227-story.html

Rose-Redwood, Reuben. (2008). From number to name: Symbolic capital, places of memory, and the politics of street renaming in New York city. Social \& Cultural Geography, 9(4), $432-452$.

Rose-Redwood, Reuben. (2011). Rethinking the agenda of political toponymy. ACME: an International Journal for Critical Geographies, 10(1), 34-41.

Rose-Redwood, Reuben, Alderman, Derek, \& Azaryahu, Maoz. (2018). The urban streetscape as political cosmos. In Reuben Rose-Redwood, Derek Alderman, \& Maoz Azaryahu (Eds.), The political life of urban streetscapes: Naming, politics, and place (pp. 1-24). New York, NY: Routledge.

Rose-Redwood, Reuben, \& Alderman, Derek. (2011). Critical interventions in political toponymy. ACME: an International Journal for Critical Geographies, 10(1), 1-6.

Rose-Redwood, Reuben, Alderman, Derek, \& Azaryahu, Maoz. (2010). Geographies of toponymic inscription: New directions in critical place-name studies. Progress in Human Geography, 34(4), 453-470.

Rose-Redwood, Reuben, Sotoudehnia, Maral, \& Tretter, Eliot. (2019). “Turn your brand into a destination": Toponymic commodification and the branding of place in Dubai and Winnipeg. Urban Geography. doi: 10.1080/02723638.2018.1511191

Scauzillo, Steve. (2016, December 7). LA County Metro seeing \$\$\$ with new opportunity to sell naming rights to rail lines, stations. San Gabriel Valley Tribune. Retrieved from https://www. sgvtribune.com/2016/12/07/la-county-metro-seeing-with-new-opportunity-to-sell-namingrights-to-rail-lines-stations

Scauzillo, Steve. (2017, February 24). Metro rescinds policy to sell corporate naming rights to rail lines, stations. San Gabriel Valley Tribune. Retrieved from https://www.sgvtribune.com/2017/ 02/24/metro-rescinds-policy-to-sell-corporate-naming-rights-to-rail-lines-stations 
Sotoudehnia, Maral. (2013). "Turn your brand into a destination": City branding, naming rights, and the neoliberalization of Dubai, UAE (Unpublished Masters dissertation). Department of Geography, University of Victoria.

Sotoudehnia, Maral. (2018). Toponymic checksum or flotsam? Recalculating Dubai's grid with Makani, "the smartest map in the world.". In Reuben Rose-Redwood, Derek Alderman, \& Maoz Azaryahu (Eds.), The political life of urban streetscapes: Naming, politics, and place (pp. 290-308). London: Routledge.

Sotoudehnia, Maral, \& Rose-Redwood, Reuben. (2019). "I am Burj Khalifa": Entrepreneurial urbanism, toponymic commodification, and the worlding of Dubai. International Journal of Urban and Regional Research. doi: 10.1111/1468-2427.12763

Vuolteenaho, Jani, \& Ainiala, Terhi. (2009). Planning and revamping urban toponymy: Ideological alternations in the linguistic landscaping of Vuosaari suburb, eastern Helsinki. In Lawrence Berg \& Jani Vuolteenaho (Eds.), Critical toponymies: The contested politics of place naming (pp. 227-251). Farnham: Ashgate.

Vuolteenaho, Jani, \& Kolamo, Sami. (2012). Textually produced landscape spectacles? A Debordian reading of Finnish namescapes and English soccerscapes. In Jani Vuolteenaho, Andrew Newby, Lieven Ameel, \& Maggie Scott (Eds.), Language, space and power: Urban entanglements (pp. 132-158). Helsinki: Helsinki Collegium for Advanced Studies.

Vuolteenaho, Jani, \& Puzey, Guy. (2018). "Armed with an encyclopedia and an axe": The socialist and post-socialist street toponymy of East Berlin revisited through Gramsci. In Reuben Rose-Redwood, Derek Alderman, \& Maoz Azaryahu (Eds.), The political life of urban streetscapes: Naming, politics, and place (pp. 74-97). New York, NY: Routledge.

Vuolteenaho, Jani, Wolny, Matthias, \& Puzey, Guy. (2019). “This venue is brought to you by ... ”: The diffusion of sports and entertainment facility name sponsorship in urban Europe. Urban Geography. doi: 10.1080/02723638.2018.1446586

Wanjiru, Melissa Wangui, \& Matsubara, Kosuke. (2017). Street toponymy and the decolonisation of the urban landscape in post-colonial Nairobi. Journal of Cultural Geography, 34(1), 1-23.

Woisetschläger, David, Haselhoff, Vanessa, \& Backhaus, Christof. (2014). Fans' resistance to naming right sponsorships: Why stadium names remain the same for fans. European Journal of Marketing, 48(7/8), 1487-1510.

Wright, John Kirtland. (1929). The study of place names: Recent work and some possibilities. Geographical Review, 19(1), 140-144.

Yeoh, Brenda. (1996). Street-naming and nation-building: Toponymic inscriptions of nationhood in Singapore. Area, 28(3), 298-307.

Yurchak, Alexei. (2000). Privatize your name: Symbolic work in a post-Soviet linguistic market. Journal of Sociolinguistics, 4(3), 406-434. 